\title{
BACTERIAL CONTAMINATION OF THE CATFISH (Cathorops agassizii - Valenciennes, 1839 and Genidens genidens - Agassiz, 1829) STING
}

Thesis: M. E. P. JUNQUEIRA submitted this dissertation for his Masters in Tropical Diseases at Botucatu School of Medicine, São Paulo State University, UNESP, Botucatu, São Paulo, Brazil, 2003.

Advisor: Professor Carlos Alberto de Magalhães Lopes.

ABSTRACT: This work aimed to study the bacterial contamination in stings of the catfish Genidens genidens and Cathorops agassizii found in the São Vicente estuarine system (São Paulo State, Brazil). For bacteriological analyses, we used fish samples distributed into a group of 50 specimens (25 C. agassizii and $25 \mathrm{G}$. genidens) and a group of 14 specimens ( $7 \mathrm{C}$. agassizii and $7 \mathrm{G}$. genidens). Results showed contamination of 13 different bacterial species of Enterobacteriaceae, being Klebsiella pneumoniae the most frequent bacteria (26.80\%) followed by Enterobacter sp and Escherichia coli (16.27\%), and Serratia marcescens, Serratia sp. and Proteus mirabilis (1.16\%). Gram-positive bacteria as well as fungi were not detected in the samples. According to the Gram-negative species characterized and with regard to the environmental conditions, it can also be considered that accidents with these catfish stings may develop significant acute secondary infections in humans.

KEY WORDS: Cathorops agassizii, Genidens genidens, sting venom.

\section{CORRESPONDENCE TO:}

MARCOS EMERSON PINHEIRO JUNQUEIRA, Departamento de Microbiologia e Imunologia, Instituto de Biociências, UNESP, Botucatu, SP, 18618-000, Brasil. Email: lopescam@ibb.unesp.br 